\title{
Multifocal juvenile xanthogranuloma
}

\author{
Wieloogniskowa żółtakoziarniniakowatość młodzieńcza
}

Piotr Jarliński, Jolanta Węgłowska

Dermatology Ward with Pediatric Dermatology Unit, The District Tertiary Hospital, Wroclaw, Poland

Oddział Dermatologiczny z Pododdziałem Dermatologii Dziecięcej, Wojewódzki Szpital Specjalistyczny, Wrocław, Polska

Dermatol Rev/Przegl Dermatol 2020, 107, 44I-446

DOI: https://doi.org/| 0.5 | |4/dr.2020. 10 | 67 |

\section{CORRESPONDING AUTHOR/ ADRES DO KORESPONDENCJI:}

lek. Piotr Jarliński MD

Oddział Dermatologiczny

z Pododdziałem

Dermatologii Dziecięcej

Wojewódzki Szpital

Specjalistyczny

ul. H. M. Kamieńskiego 73a

51-124 Wrocław

tel.: +48 601155051

e-mail: piotr.jarlinski@gmail.com

\begin{abstract}
Introduction. Xanthogranuloma juvenile is the most common type of non-Langerhans cell histiocytosis. Most often it occurs in the form of solitary skin nodules, however, extracutaneous localization of lesions is also possible.
\end{abstract}

Objective. To present the case of a patient with confirmed juvenile xanthogranuloma, and to review the literature on the subject.

Case report. A 3-month-old boy was admitted to the hospital for diagnostics of skin nodules with concomitant changes in the subcutaneous tissue. Juvenile exanthogranuloma was suspected. The ultrasound scanning of the abdominal cavity revealed numerous focal lesions within internal organs. Based on the histopathological examination of a skin nodule and of a nodule of the subcutaneous tissue in the lumbar region, the diagnosis of multifocal juvenile xanthoganuloma was made.

Conclusions. Juvenile xanthogranuloma usually affects the skin only. In these cases the course of the disease is usually mild, with a tendency to self-healing. In cases with extracutaneous lesions, the course of the disease depends on location of lesions and their effect on function of affected organs. In the case of involvement of vital areas, surgical removal, chemotherapy or immunosuppressive treatment is recommended.

\section{STRESZCZENIE}

Wprowadzenie. Żółtakoziarniniakowatość młodzieńcza (xanthogranuloma juvenile) jest najczęstszym rodzajem histiocytozy z komórek nie-Langerhansa. Najczęściej występuje w postaci pojedynczych guzków skórnych, możliwa jest jednak również pozaskórna lokalizacja zmian w przebiegu choroby.

Cel pracy. Przedstawienie przypadku pacjenta z rozpoznaną wieloogniskową żółtakoziarniniakowatością młodzieńczą oraz przegląd piśmiennictwa dotyczącego tego zagadnienia.

Opis przypadku. Trzymiesięczny chłopiec został przyjęty na oddział w celu diagnostyki guzków skórnych ze współistniejącymi zmianami w tkance podskórnej. Postawiono podejrzenie żółtakoziarniniakowatości młodzieńczej. W badaniu ultrasonograficznym jamy brzusznej stwierdzono liczne zmiany ogniskowe w obrębie narządów wewnętrznych. Na podstawie badania histopatologicznego guzka skóry oraz guza tkanki podskórnej okolicy lędźwiowej ustalono rozpoznanie wieloogniskowej żółtakoziarniniakowatości młodzieńczej. 
Wnioski. Żółtakoziarniniakowatość młodzieńcza najczęściej dotyczy wyłącznie skóry. Przebieg jest wówczas łagodny, z tendencją do samowyleczenia. W przypadku obecności zmian pozaskórnych przebieg zależy od lokalizacji zmian i wpływu na funkcję zajętych organów. W razie zajęcia ważnych dla życia okolic zaleca się chirurgiczne usunięcie, chemioterapię lub leczenie immunosupresyjne.

Key words: xanthogranuloma juvenile, multifocal.

Słowa kluczowe: żółtakoziarniniakowatość młodzieńcza, wieloogniskowa.

\section{INTRODUCTION}

Xanthogranuloma juvenile (JGX) is the most common type of non-Langerhans cell histiocytosis. In most cases, it appears as single or multiple compact yellowish skin nodules that tend to disappear spontaneously after several months or years. In some cases, the presence of extracutaneous lesions is observed multifocal juvenile xanthoganuloma (multifocal JGX). Lesions can develop within the subcutaneous tissue, eyeball, salivary gland, and practically any internal organ.

\section{OBJECTIVE}

The purpose of the study is to present a case of a 3-month-old boy diagnosed with multifocal juvenile xanthoganuloma and to review the literature on the subject.

\section{CASE REPORT}

A 3-month-old boy was admitted to the Ward for the diagnostics of small yellowish nodules, about $10 \mathrm{~mm}$ in diameter, located behind the right ear and on the skin of the right lower limb (figs. $1 \mathrm{~A}, \mathrm{~B}$ ). The lesions appeared in the second month of life and did not cause any symptoms in the child. The patient was in good general condition, and his parents did not report any disturbing symptoms of systemic nature. The reason for visiting the Outpatient Clinic was the appearance of further lesions - cohesive subcutaneous nodules in the left cheek area, in the lumbar region and in the area of the right knee. Soft tissue ultrasound scanning performed in outpatient setting confirmed the presence of highly hypoechogenic, non-vascular nodular structures in the described areas.

A section of the nodule from the skin of the lower leg was taken for histopathological examination. Based on the clinical presentation xanthogranuloma

\section{WPROWADZENIE}

Żółtakoziarniniakowatość młodzieńcza (xanthogranuloma juvenile - JGX) jest najczęstszym rodzajem histiocytozy wywodzącej się z komórek nie-Langerhansa. W większości przypadków występuje w postaci pojedynczych lub mnogich, spoistych, żółtawych guzków skórnych, które mają tendencję do samoistnego zanikania po kilku miesiącach lub latach. W niektórych przypadkach obserwuje się obecność zmian pozaskórnych [wieloogniskowa żółtakoziarniniakowatość młodzieńcza (multifocal JG)]. Mogą się one pojawić w obrębie tkanki podskórnej, gałki ocznej, ślinianki i każdego innego narządu wewnętrznego.

\section{CEL PRACY}

Celem pracy jest przedstawienie przypadku 3-miesięcznego chłopca z rozpoznaną wieloogniskową żółtakoziarniniakowatością młodzieńczą oraz przegląd piśmiennictwa dotyczącego tego zagadnienia.

\section{OPIS PRZYPADKU}

Trzymiesięczny chłopiec został przyjęty na oddział w celu diagnostyki drobnych, żółtawych guzków o wielkości ok. $10 \mathrm{~mm}$ zlokalizowanych za prawym uchem i na skórze kończyny dolnej prawej (ryc. 1 A, B). Zmiany pojawiły się w drugim miesiącu życia i nie powodowały u dziecka objawów podmiotowych. Pacjent był w stanie ogólnym dobrym, rodzice nie zgłaszali żadnych niepokojących objawów choroby ogólnoustrojowej. Powodem zgłoszenia się do poradni było pojawienie się kolejnych zmian - spoistych podskórnych guzów na lewym policzku, w okolicy lędźwiowej oraz w obrębie prawego kolana. Wykonane w trybie ambulatoryjnym badanie ultrasonograficzne (USG) tkanek miękkich potwierdzało obecność silnie hipoechogennych, nieunaczynionych struktur guzowatych w opisywanych obszarach. 

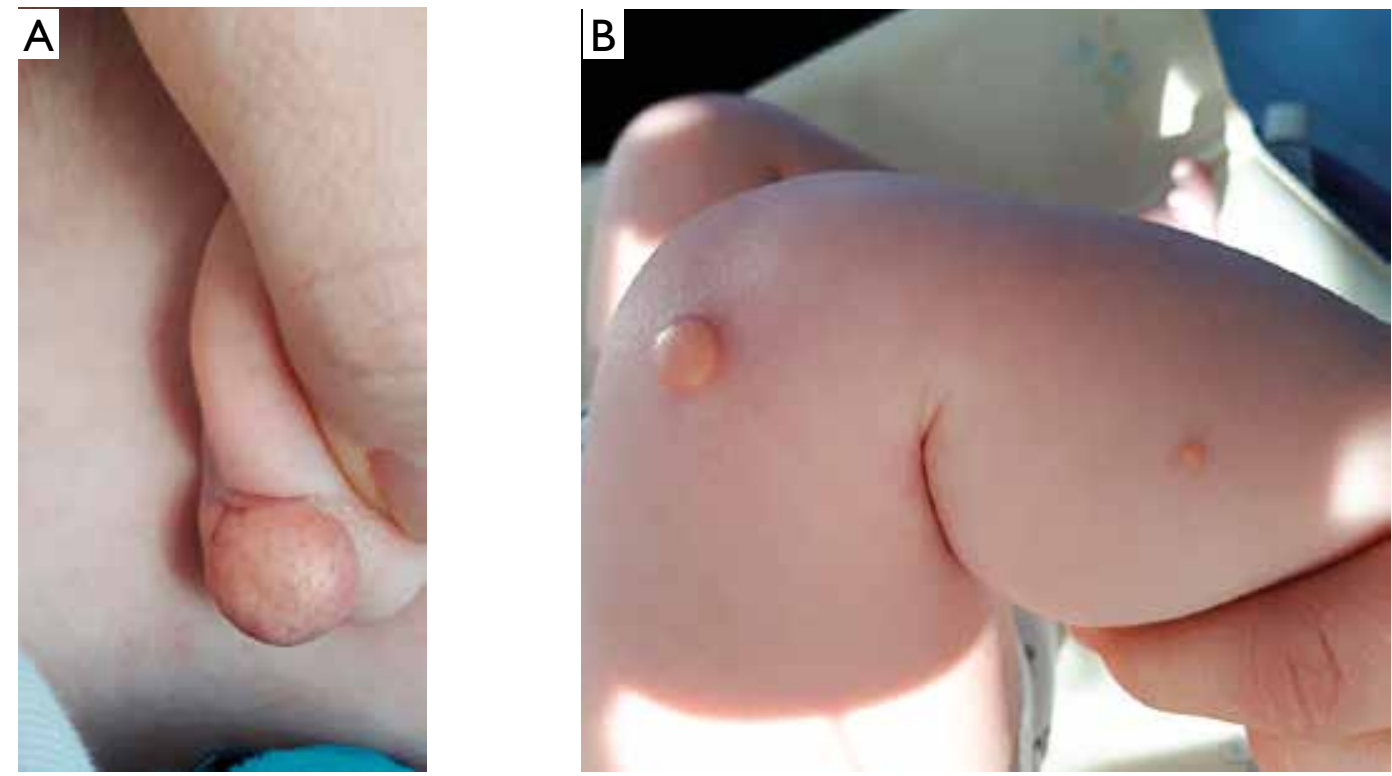

Figure I. Skin nodules

Rycina I. Guzki
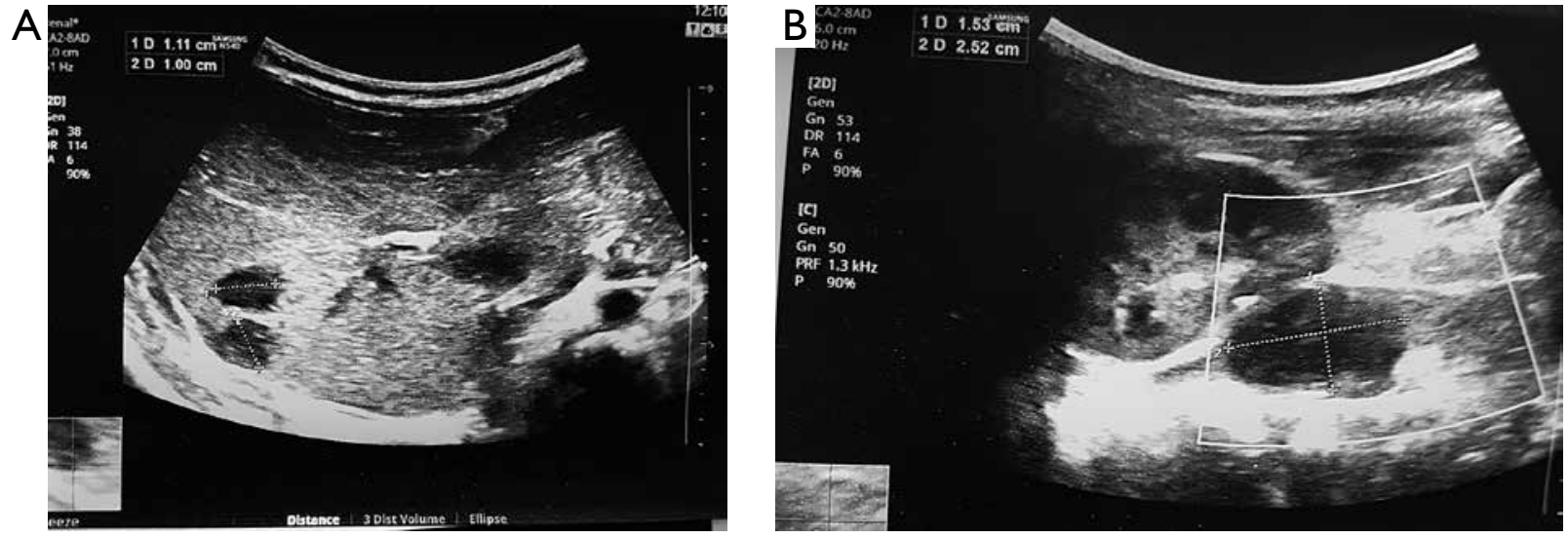

Figure 2. Ultrasound presentation: $\mathbf{A}$ - lesions within the liver, $\mathbf{B}$ - a nodule in the area of the left kidney

Rycina 2. Obraz ultrasonograficzny: A - zmiany w obrębie wątroby, B - guz w okolicy lewej nerki

juvenile was suspected. Ultrasound examination of the abdominal cavity was also ordered. The examination revealed numerous heterogeneous, well-defined, hypoechoic, focal lesions in the liver, spleen and the area of the left kidney (figs. 2 A, B). After an ophthalmologic consultation that showed no pathologies, the patient was discharged with the suspicion of multifocal juvenile xanthogranuloma, in order to perform a full-body magnetic resonance imaging (MRI) and to decide on further treatment.

According to the parents, the child had an MRI of the chest and abdominal cavity done - the examination confirmed the presence of lumpy masses detected in ultrasound (US) of the abdominal cavity. No abnormalities were found in the chest area. A therapeutic and diagnostic removal of a nodule from the lumbar region was also performed (histopathological examination confirmed the diagnosis of multifocal JXG). Due
Pobrano wycinek z guzka na skórze podudzia do badania histopatologicznego. Na podstawie obrazu klinicznego powzięto podejrzenie żółtakoziarniniakowatości młodzieńczej (xanthogranuloma juvenile). Zlecono również USG jamy brzusznej. W badaniu wykazano liczne niejednorodne, dobrze odgraniczone, hipoechogenne zmiany ogniskowe w obrębie wątroby, śledziony i w okolicy lewej nerki (ryc. 2 A, B). Po konsultacji okulistycznej, która nie wykazała nieprawidłowości, wypisano pacjenta z podejrzeniem wieloogniskowej żółtakoziarniniakowatości młodzieńczej z zaleceniem wykonania rezonansu magnetycznego całego ciała (magnetic resonance imaging - MRI) i podjęcia decyzji o dalszym postępowaniu.

Według relacji rodziców dziecko miało wykonane MRI klatki piersiowej i jamy brzusznej - badanie potwierdziło obecność wykrytych w USG jamy brzusznej mas guzowatych. Nie stwierdzono odchyleń od 


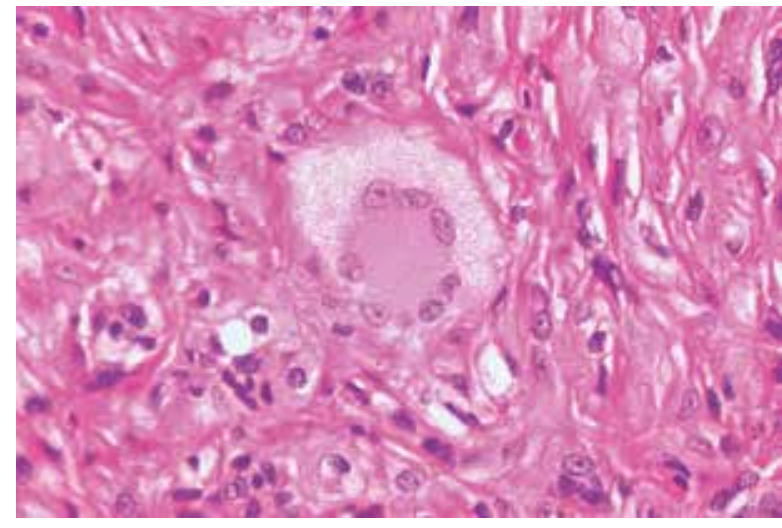

Figure 3. The Touton cell. From. Ed Uthman, https://www.flickr.com/ photos/euthman/809705086 |/in/album-72057594 | | 409978 I/ (with the consent of the author)

Rycina 3. Komórka Toutona. Fot. Ed Uthman, https://com/photos/euthman/809705086 I/in/album-72057594 I | 409978 I/ (za zgodą autora)

to the absence of symptoms from abdominal organs, a wait-and-see strategy was adopted. The patient remains under supervision of the Teaching Department of Pediatric Hematology and waits for a control MRI of the abdominal cavity and of the central nervous system (CNS) to determine further treatment.

\section{DISCUSSION}

Xanthogranuloma juvenile is the most common type of non-Langerhans cell histiocytosis. We owe the first description of the disease to Adamson (1905) [1] In 1912 McDonagh defined the changes corresponding to Adamson's description as nevoxanthoendothelioma [2]. The name xanthogranuloma juvenile was given in 1954 by Helwig and Hackney [3].

In most cases, the disease develops as single, cohesive, yellowish, asymptomatic skin nodules approximately $1 \mathrm{~cm}$ in size. The most typical localization of lesions is the head, neck and torso area [4]. The disease is usually mild, with a tendency to spontaneous disappearance of nodules after a few months or years, leaving a slight atrophic scar or discoloration $[5,6]$. In dermoscopy, skin lesions resemble a patchy, yellow structure surrounded by an orange halo (so called "setting sun") [7]. In the histopathological examination, Tuton cells are characteristic, i.e. multinucleated giant cells with a crown of cell nuclei, surrounded by a foam-like bright cytoplasm (fig. 3). They are not present in all lesions, so most often an additional immunohistochemical test is performed using markers such as CD68, vimentin (positive expression in JXG) or S-100, CD1a (no or little expression) [3, 8].

A disseminated form of the disease is possible, with the presence of numerous disseminated nodules (disseminated JXG) scattered all over the skin. normy w obrębie klatki piersiowej. Wykonano również leczniczo-diagnostyczne usunięcie guza okolicy lędźwiowej (badanie histopatologiczne potwierdziło rozpoznanie multifocal JXG). W związku z brakiem objawów ze strony narządów jamy brzusznej przyjęto strategię wyczekującą. Pacjent jest pod opieką Kliniki Hematologii Dziecięcej i oczekuje na kontrolny MRI jamy brzusznej oraz rezonans ośrodkowego układu nerwowego (OUN) w celu ustalenia dalszego postępowania.

\section{OMÓWIENIE}

Żółtakoziarniniakowatość młodzieńcza jest najczęstszym rodzajem histiocytozy wywodzącej się z komórek nie-Langerhansa. Pierwszy opis choroby zawdzięczamy Adamsonowi (1905 r.) [1]. W 1912 r. McDonagh określił zmiany odpowiadające opisowi Adamsona jako nevoxanthoendothelioma [2]. Nazwę xanthogranuloma juvenile nadali chorobie w $1954 \mathrm{r}$. Helwig i Hackney [3].

Choroba w większości przypadków występuje $\mathrm{w}$ postaci pojedynczych spoistych, żółtawych, asymptomatycznych guzków skórnych o wielkości ok. $1 \mathrm{~cm}$. Najbardziej typową lokalizacją zmian jest obszar głowy i szyi oraz tułów [4]. Choroba zazwyczaj przebiega łagodnie, $\mathrm{z}$ tendencją do samoistnego zanikania guzków po kilku miesiącach lub latach z pozostawieniem niewielkiej zanikowej blizny lub przebarwienia $[5,6]$. W dermatoskopii zmiany skórne mają wygląd niejednolitej, żółtej struktury otoczonej pomarańczową obwódką (objaw zachodzącego słońca) [7]. W badaniu histopatologicznym charakterystyczne są komórki Tutona, czyli wielojądrzaste komórki olbrzymie z wieńcem jąder komórkowych, otoczone piankowatą jasną cytoplazmą (ryc. 3). Nie są one obecne we wszystkich zmianach, najczęściej wykonuje się więc dodatkowo badanie immunohistochemiczne, wykorzystując takie markery, jak CD68, wimentyna (dodatnia ekspresja w JXG) lub S-100, CD1a (brak lub niewielka ekspresja) $[3,8]$.

Możliwa jest rozsiana postać choroby z obecnością bardzo licznych guzków rozproszonych na całej skórze (disseminated JXG). W niektórych przypadkach obserwuje się zmiany pozaskórne (multifocal JXG). Mogą one wystąpić w obrębie tkanki podskórnej, gałki ocznej, ślinianki, a także każdego innego narządu wewnętrznego (wątroba, nerki, śledziona, trzustka, płuca, OUN, kości) [9-15]. Zmiany narządowe mogą wpływać na przeżycie pacjentów, prowadząc do niewydolności narządowej, ucisku otaczających struktur lub krwotoków [16, 17]. W przypadku zajęcia ważnych dla życia okolic zaleca się chirurgiczne usunięcie zmiany, a w razie braku takiej możliwości chemioterapię (winblastyna) lub leczenie immunosupresyjne (prednizon, metotreksat) [18]. 
In some cases, the presence of extracutaneous lesions (multifocal JXG) is observed. Lesions can occur within the subcutaneous tissue, eyeball, salivary gland, and practically any internal organ (liver, kidneys, spleen, pancreas, lungs, CNS, bones) [9-15]. Organ changes may affect the survival of patients, leading to organ failure, compression of surrounding structures or hemorrhages $[16,17]$. In the case of involvement of vital areas, surgical removal of lesions is recommended. If that is not feasible, chemotherapy (vinblastine) or immunosuppressive treatment (prednisone, methotrexate) should be applied [18].

Juvenile xanthoganuloma may coexist with neurofibromatosis type 1 and juvenile myelomonocytic leukemia, hence the need to test each patient for other symptoms characteristic of neurofibromatosis type 1 and perform basic laboratory tests (blood count with smear).

\section{CONCLUSIONS}

Xanthoganuloma juvenile is a non-Langerhans cell histiocytosis mostly affecting the skin only. In that case its course is mild, with a tendency to spontaneous resolution of skin lesions. In the case of the presence of extracutaneous lesions, the course depends on location of changes and their impact on vital structures. In those cases, an interdisciplinary treatment is necessary, combining surgical specialties (surgery, neurosurgery, ophthalmology, ENT) as well as nonsurgical ones (hematology, dermatology).
Żółtakoziarniniakowatość młodzieńcza może współistnieć z neurofibromatozą typu 1 i młodzieńczą białaczką mielomonocytową, dlatego konieczne jest badanie każdego pacjenta pod kątem innych charakterystycznych dla neurofibromatozy objawów i wykonanie podstawowych badań laboratoryjnych (morfologia krwi z rozmazem).

\section{PODSUMOWANIE}

Żółtakoziarniniakowatość młodzieńcza to histiocytoza z komórek nie-Langerhansa, która najczęściej dotyczy wyłącznie skóry. Przebieg jest w tych przypadkach łagodny, z tendencją do samoistnego zaniku zmian skórnych. W razie obecności zmian pozaskórnych przebieg zależy od lokalizacji zmian i ich wpływu na ważne dla życia struktury. W takich przypadkach konieczne jest interdyscyplinarne leczenie łączące specjalności zabiegowe (chirurgia, neurochirurgia, okulistyka, laryngologia) i niezabiegowe (hematologia, dermatologia).

\section{KONFLIKT INTERESÓW}

Autorzy nie zgłaszają konfliktu interesów.

\section{CONFLICT OF INTEREST}

The authors declare no conflict of interest.

\section{References \\ Piśmiennictwo}

1. Adamson N.F.: Congenital xanthoma multiplex in a child. Br J Dermatol 1905, 17, 222-223.

2. McDonagh J.E.R.: A contribution to our knowledge of the naevo-xantho-endothelioma. Br J Dermatol 1912, $24,85-99$.

3. Helwig E.B., Hackney V.C.: Juvenile xanthogranuloma (nevoxanthoendothelioma). Am J Pathol 1954, 30, 365-366.

4. Dehner L.P.: Juvenile xanthogranulomas in the first two decades of life. Am J Surg Pathol 2003, 27, 579-593.

5. Höck M., Zelger B., Schweigmann G., Brunner B., Zelger B., Kropshofer G.: The various clinical spectra of juvenile xanthogranuloma: imaging for two case reports and review of the literature. BMC Pediatr 2019, 19, 128.

6. Cypel T.K., Zuker R.M.: Juvenile xanthogranuloma: case report and review of the literature. Can J Plast Surg 2008, 16, 175-177.

7. Palmer A., Bowling J.: Dermoscopic appearance of juvenile xanthogranuloma. Dermatology 2007, 215, 256-259.

8. Raj D., Rathy R.: Juvenile xanthogranuloma: a case report. Int J Odontostomat 2018, 12, 327-331.

9. Cauro F., Houtteville J.P., Mesnil J.L., Guarnieri J.: Cerebellar, pulmonary and cutaneous localizations of juvenile xanthogranuloma. Ann Dermatol Venereol 2002, 129, 307-310.

10. Sangüeza O.P., Salmon J.K., White C.R. Jr, Beckstead J.H.: Juvenile xanthogranuloma: a clinical, histopathologic and immunohistochemical study. J Cutan Pathol 1995, 22, 327-335.

11. Chang M.W.: Update on juvenile xanthogranuloma: unusual cutaneous and systemic variants. Semin Cutan Med Surg 1999, 18, 195-205.

12. Liang S., Liu Y.H., Fang K.: Juvenile xanthogranuloma with ocular involvement. Pediatr Dermatol 2009, 26, 232-234.

13. Lesniak M.S., Viglione M.P., Weingart J.: Multicentric parenchymal xanthogranuloma in a child: case report and review of the literature. Neurosurgery 2002, 51, 1493-1498. 
14. Neveling U., Kahn L.B., Valderrama E., Poustchi-Amin M., Uckan D., Shende A.: Deep juvenile xanthogranuloma: an unusual presentation. Pediatr Pathol Lab Med 1997, 17, 503-511.

15. Ginat D.T., Vargas S.O., Silvera V.M., Volk M.S., Degar B.A., Robson C.D.: Imaging features of juvenile xanthogranuloma of the pediatric head and neck. Am J Neuroradiol 2016, 37, 910-916.

16. Gohari A.R., Reith J., Scarborough M., Khuddus N., Ratnakaram R., Park H.J., et al.: Multifocal juvenile xanthogranuloma presenting with a hand mass and bilateral vitreous hemorrhage in a neonate. Retin Cases Brief Rep 2010, 4, 346-351.

17. Freyer D.R., Kennedy R., Bostrom B.C., Kohut G., Dehner L.P.: Juvenile xanthogranuloma: forms of systemic disease and their clinical implications. J Pediatr 1996, 129, 223-227.

18. Cichewicz A., Białecka A., Męcińska-Jundziłł K., Adamska U., Białecki M., Neska-Długosz I., et al.: Congenital multiple juvenile xanthogranuloma. Adv Dermatol Allergol 2019, 36, 365-368.

Received: 28.05 .2020

Accepted: 4.10.2020

Otrzymano: $28.05 .2020 \mathrm{r}$

Zaakceptowano: $4.10 .2020 \mathrm{r}$.

How to cite this article

Jarliński P., Węgłowska J.: Multifocal juvenile xanthogranuloma. Dermatol Rev/Przegl Dermatol 2020, 107, 441-446. DOI: https://doi.org/10.5114/dr.2020.101671. 